\title{
Javanese Culture Maintenance by Utilizing Natural Resources for Traditional Cuisine to Promote Tegal City Culinary Tourism
}

\author{
R.Aj. Atrinawati ${ }^{1}$ \\ ${ }^{1}$ English Literature Study Program, Linguistics Department, Faculty of Humanities, Diponegoro \\ University, Semarang, Indonesia
}

\begin{abstract}
Utilizing local natural resources in traditional cuisines is done to maintain local tradition and culture reflecting local wisdom. This research shows how Tegal City use local vegetable and meat in traditional cuisine to keep the livestock and crops stock, to preserve the tradition and culture embedded in the cuisine, and to promote the culinary tourism. It was done by holding a folklore field research to collect and analyze the data. The result shows that those efforts are beneficial for the local people to preserve their natural resources, tradition, and business that maintain their local identity as part of their local culture.
\end{abstract}

\section{Research Background}

Culture is defined in many ways, including what Koentjaraningrat said as a complete system of the idea, act, and human being created as part of their society [1]. Since culture is human being creation, it can be inherited, created, or learned. Therefore, people can inherit a culture from their ancestors, create a new culture for their society, or learn from other societies. One of the examples of culture as part of human being creation is tradition. One of many examples of tradition is the tradition of cooking traditional cuisines. Local people keep the old ways of cooking, serving, and consuming traditional food in particular occasions inherited from their ancestors and passed from generation to generation as part of their local tradition.

Culture is also defined as knowledge, belief, art, morals, laws, custom, and human beings' capabilities and habits in their society [2]. Thus, traditional cuisine belongs to culture as it is part of society's knowledge, custom, cooking capabilities, and habits of consuming the food in particular traditional or cultural events. Since culture can be history when people possessing the culture no longer keep it, culture should be maintained by preserving or modifying it. Keeping traditional cuisine is one of many ways to preserve culture since it will also maintain society's history and way of life reflecting their culture. This research shows how Tegal City people utilize their abundant natural resources such as livestock and crops as the ingredient of their traditional cuisines, which were offered as Tegal City traditional culinary tourism items to maintain their tradition, local identity, and local culture. 


\section{Theoretical Background}

Culture Culture can be defined as people's way of thinking and way of life that make them able to run their lives in their society. Javanese culture reflects Javanese people's way of thinking and life, making them live well in their society from the ancient until the modern era. When people as the culture owner still keep it in their lives, culture can be passed from generation to generation. However, when the culture owner no longer keeps it, uses it, or passes it to the next generation, culture can become extinct and become history, which is only written as a manuscript or told as a story.

When culture no longer exists in a society, people's way of thinking and life is also gone since it is substituted with a new one that is considered more beneficial by the new generation. To maintain the culture, the society should put an effort supported by the authority to keep using and passing it. Since culture can be divided into many forms of human being creation, culture can also be maintained through one of many culture form maintenances. It is done to avoid the culture shift, extinction, and dead when it is only used and kept by the minorities or taken by others since political, economic, and social changes can change people's attitude toward a culture that reduces its value, usage, and respect [3].

One of the ways to maintain a culture can be done by keeping traditional cuisine using local ingredients which preserve a local tradition as part of local culture. This research exposes 8 (eight) traditional cuisines maintained by Tegal City people and selected by visitors as the leading traditional culinary attraction that made the local government support the business by putting it in the city tourism promotion

\section{Methodology}

This research belongs to descriptive and qualitative research. It explains Tegal City's people and local government effort to maintain its culture by preserving their tradition by keeping the old ways of cooking, serving, and consuming 8 (eight) old and traditional cuisines. Those cuisine items were chosen using the Purposive Sampling Technique [4] by selecting the famous traditional culinary tourism in Tegal City. The data were obtained by using Dundes [5] two Folklore Methods named Identification and Interpretation.

The first method, which is objective and empirical, collected the data using the Documentation Method [6] to get written information from various sources. Through the second method, which is subjective and speculative, the data were gathered by using Participatory Observation, Note Taking, and Recording Techniques [4] to get information from local informants. Those methods were used to obtain complete information and a comprehensive explanation of the history, the ingredients, how it is cooked, served, and consumed, the story behind its name, and how it attracts people to taste it.

\section{Finding and Discussion}

\subsection{Finding}

\subsubsection{Sega Ponggol and Sega Lengko}

Sega Ponggol is a traditional cuisine for breakfast consisting of rice with a kind of oreg tempe named ponggol as the main dish on top of the rice and orange kerupuk (traditional crackers) topping that can be added with various side dishes such as fried noodle or cucumber 
pickle. It is usually served in banana leaves wrapping as bekal (box) taken home or brought to the workplace.

Meanwhile, Sega Lengko is a traditional cuisine for breakfast or lunch consisting of rice with small chopped fried tempeh and yellow tofu, hot water-soaked bean sprouts, and minced cucumber toppings as side dishes. It is then smothered with peanut sauce, added soy sauce, and sprinkled with yellow krupuk mie. It is usually served on a plate and consumed right after it is directly prepared on the food stalls by the sellers.

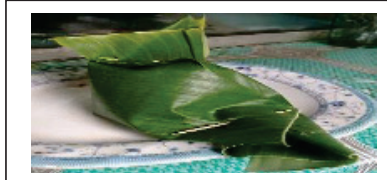

1.a

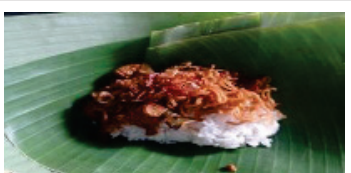

$1 . \mathrm{b}$

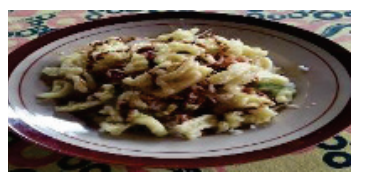

1.c

Fig. 1 Sega Ponggol (1.a and 1.b) and Sega Lengko (1.c).

\subsubsection{Sate Kambing Tirus and Sate Ayam Sidjan}

For lunch or dinner, sate Kambing Tirus is a traditional cuisine consisting of medium cooked goat satay, smothered with soy sauce and added with minced onion, tomato, and cabai rawit (small green cayenne chilli). This satay is famous for its chewy mutton served while it is hot.

Meanwhile, Sate Ayam Sidjan is a traditional cuisine for dinner consisting of chicken (meat and skin) satay, smothered with peanut sauce and added with soy sauce, minced onion, tomato, and boiled cabai rawit. This satay is famous for its big cutting meat and skin and tasty peanuts sauce.

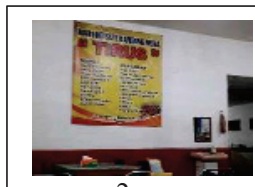

2.a

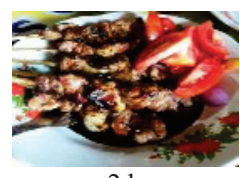

2.b

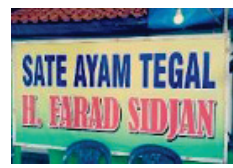

2.c

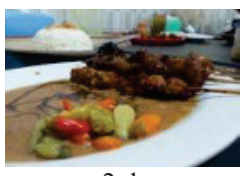

2.d

Fig. 2. Sate Kambing Tirus (2.a and 2.b) and Sate Ayam Sidjan (2.c and 2.d).

\subsubsection{Kupat Glabed and Kupat Bongkok}

Kupat Glabed is a traditional cuisine for lunch or dinner consisting of kupat (rice, filled in coconut leaves specially formed into a kind of rhombus shape, and then boiled until it is cooked). It is chopped and smothered with thick (ngglabed) opor sauce and added with sambal goreng, fried onion, and yellow kerupuk mie (traditional crackers) as toppings.

Meanwhile, Kupat Bongkok is a traditional cuisine for breakfast consisting of kupat lontong (rice, filled in banana leaves specially formed into a kind of rectangular shape, and then boiled until it is cooked). It is chopped, put in plastic, and smothered with bongkok sauce (light opor sauce cooked with thick tempeh puree). It is added with sambal goreng, fried onion, and kerupuk mie as toppings. 


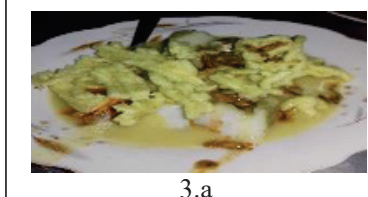

$3 . \mathrm{a}$

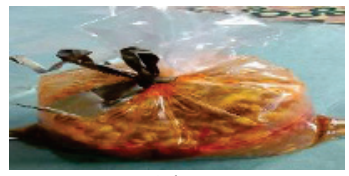

3.b

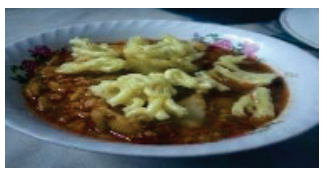

3.c

Fig. 3. Kupat Glabed (3.a) and Kupat Bongkok (3.b and 3.c).

\subsubsection{Sauto Tegal}

Sauto is a traditional cuisine for lunch or dinner consisting of sauto (chicken soup with fermented bean sauce seasoning named tauco) that can be served with rice or lontong (rice, filled in banana leaves which is specially formed into a cylinder shape and then boiled until it is cooked). It is then added with hot water-soaked bean sprouts, minced scallions, and fried onion as toppings. There are two famous sauto sellers, Pasar Senggol and Sedep Malem.

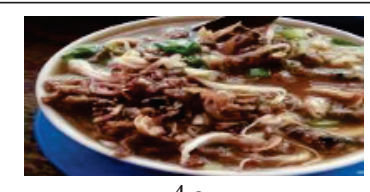

4.a

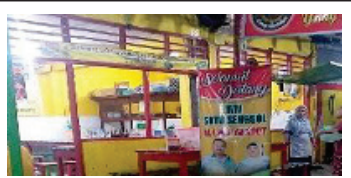

4.b

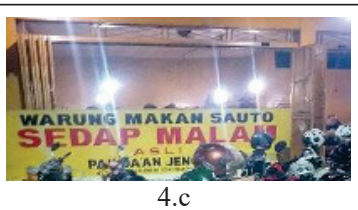

4.c

Fig. 4. Sauto (4.a), Sauto Pasar Senggol (4.b), and Sauto Sedep Malem (4.d).

\subsubsection{Glotak}

Glotak is a traditional cuisine as snack made of beef and chicken bones broth, added with hot and spicy steamed gembus (tofu dregs) puree and served along with the chicken bones. This snack is usually found in school canteen or street food stall near offices or kampongs. Buyers commonly take it away and consume it with krupuk antor as topping.

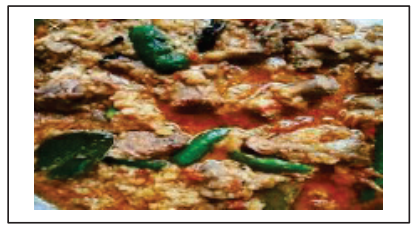

Fig. 5. Glotak.

\subsection{Discussion}

\subsubsection{Sega Ponggol and Sega Lengko}

Sega Ponggol is Tegal City's old cuisine that is commonly served as a breakfast menu. It was previously made for sugar cane laborers in Tegal Regency and Brebes District who work in the sugar cane field for two big sugar factories in the Tegal area. They were given sega ponggol by their families or the sugar cane factory owner/management for breakfast and lunch so that they could go earlier in the morning without having breakfast at home first or 
do not have to go back home for lunch in the afternoon as it took ample of time to go back and forth from the sugar cane field to their home or the factory.

Sega Ponggol is made by cooking the rice first. And then cooking tempeh into a kind of oreg named ponggol by sauteing chopped onion, garlic, and chili first before adding small chopped tempeh and putting dense coconut milk to get a very thick sauce on the tempeh. Add soy sauce to get the brown color and the sweet taste, and then add beef/chicken broth, bay leaf, galangal, lemongrass, salt, pepper, and sugar and let it cook. Sega Ponggol is served by putting the rice on banana leave and then putting ponggol on top as the main side dish. It is added with side dishes such as fried noodles and particular orange kerupuk specially used for it and then wrapped with banana leave and taken away as breakfast or lunch box.

Nowadays, Sega Ponggol was served at midnight called Ponggol Setan or Pongset to refer to the very hot and spicy ponggol and satan or ghost who frighten people at night. It means that the hot and spicy taste of pongset frightens the buyers. In addition to its hot taste, both sellers and buyers were 'alive' at night like a ghost.

Like Sega Ponggol, Sega Lengko is Tegal City's old cuisine commonly served as a breakfast menu. However, since the material is prepared right before it is served, it does not get stale quickly. Thus, it can be served as lunch. This meal previously came from Indramayu and Cirebon (West Java). It enters Tegal City from Brebes District as the border of Central Java (Brebes) and West Java (Cirebon).

Sega Lengko is made by cooking the rice first and then frying tempeh and yellow tofu. It is served by putting the small chopped tempeh and tofu on the rice as side dishes. It is then smothered with peanut sauce, added with hot water-soaked bean sprouts, minced fresh, unpeeled cucumber, fried onion, and soy sauce on top before it is sprinkled with particular kerupuk mie on the whole dish as toppings. Nowadays, lengko is also served with lontong instead of rice. However, the tradition of serving lengko with rice is still preserved.

\subsubsection{Sate Kambing Tirus and Sate Ayam Sidjan}

Sate Kambing Tirus is Tegal City's old cuisine which is commonly served as lunch or dinner menu consisting of chopped mutton stuck in a bamboo skewer and then grilled and served before it is done (medium grilled). It is then smothered with soy sauce, added with chopped onion, tomato, and cabe rawit. This goat satay is famous for its chewy mutton as the sellers usually use young goat (three to five months old) called batibul (bawah tiga bulan) or balibul (bawah lima bulan). Then it is grilled for a while only to get the exceptionally soft and juicy medium grilled mutton taste.

Tirus is the name of a particular street area in Capt. Sudibyo Street, Tegal City, where the first owner of Sate Kambing Tirus, H. Yahya, started the business in 1980. The word tirus comes from two words, tikungan (bend of the road) and lurus (straight), referring to the location of the first food stall, which is precisely located on a straight road after the bending one.

Nowadays, there are several Sate Kambing Tirus food stalls on the same or different areas owned by the descendants of H. Yahya. All of them are serving young goat satay with the same recipe. It is common to have it as a lunch and dinner menu that can be enjoyed with families, friends, and colleagues.

Like Sate Kaming Tirus, Sate Ayam Sidjan is Tegal City's old cuisine usually served as a dinner menu consisting of big chopped chicken (meat and skin) stuck in a bamboo skewer and then grilled until it is done. It is then smothered peanut sauce, added with chopped onion, tomato, and boiled cabe rawit and soy sauce. This satay can be served rice lontong and a light opor soup containing chicken bones as the leftover of the chicken meat and skin used for the satay. 
Like Tirus, Sidjan is the name of the first owner of the chicken satay business who started selling the satay by walking around the city in 1960 using pikulan (a particular container to carry and prepare food carried out on the seller's shoulder). This satay is known for its big chopping of the chicken meat and skin that satisfied buyers only by consuming five to ten skewers.

The most famous Sate Ayam Sidjan is located in the city business square near the city hall, the great mosque, and the city square, which is also near Pasar Senggol as the center of sauto sellers in Tegal City. Nowadays, there are several Sate Ayam Sidjan food stalls around the city owned by the descendants of Sidjan. They all serve big cutting chicken meat and skin satay and light opor sauce containing chicken bones with the same traditional recipe. It is common to have it as a dinner menu that is usually taken away to be enjoyed with families, friends, and colleagues.

\subsubsection{Kupat Glabed and Kupat Bongkok}

Kupat Glabed is Tegal City old cuisine that can be served as lunch or dinner menu consisting of kupat, smothered with a very dense (ngglabed) opor sauce and added with sambal goreng, fried onion and kerupuk mie as toppings. The word glabed means very dense sauce that is almost being sticky as a result of adding corn flour or rice flour into the opor sauce.

The opor sauce is made by sauteing a puree of onion, garlic, candlenut, coriander, ginger and turmeric. And then, add dense coconut milk and corn flour or rice flour to make the sauce dense. Add chicken broth, bay leaf, galangal, lemongrass, salt, and sugar and let it cooked.

Meanwhile, Kupat Bongkok is Tegal City old cuisine that is commonly served as take away breakfast menu consisting of different kind of kupat since it is made by filling the rice into banana leaves (not coconut leave unlike the common kupat wrapper) which is specially formed into rectangular shape and then boiled until it is done. It is then smothered with bongkok sauce and added with sambal goreng, fried onion and kerupuk mie as toppings.

The bongkok sauce is made of steamed stale tempeh puree which is cooked with two different sauces. The first sauce is a sauted onion, garlic, pepper, candlenut, ginger, cutcherry, galangal, salt, pepper, and sugar puree which is added with water to make it into a light sauce. The second sauce is a sauted onion, garlic, chilli, hot water-soaked noodle, salt, pepper, and sugar puree which is added with water to make it into a dense sauce. The two sauces were smothered on the chopped kupat and then added with the toppings. There is a unique wrapping of take away Kupat Bongkok which is made by tiding the plastic container with banana leave from the kupat wrapping.

\subsubsection{Sauto Tegal}

Sauto is Tegal City old cuisine commonly served as lunch or dinner menu consisting of a kind of chicken soup named sauto which is cooked with fermented soy bean puree named tauco that is served with nasi or lontong It is then added with minced fried chicken from the chicken that is boiled to get the chicken broth for sauto, hot water-soaked bean sprouts, minced scallions, and fried onion on top.

Sauto is a form of Chinese and Javanese assimilation in which Chinese common cooking ingredient named tauco (fermented soy bean) is mixed with a kind of Javanese soup named soto. This particular kind of soto is called Tauto in Pekalongan and Sauto in Tegal. They are different on the use of hot water-soaked bean sprouts as topping and the meat. Tauto does not use bean sprout and use chopped boiled beef instead of minced fried chicken.

Sauto is made by boiling chicken to get chicken broth first. The chicken is then fried and minced for topping. Put a sauted puree of onion, garlic and candlenut into the broth and then 
add salt, pepper, and sugar. Make a puree of boiled chili and saute it first before adding tauco and water. Finally, put the sauted puree into the chicken broth to make sauto.

\subsubsection{Glotak}

Glotak is Tegal City old cuisine made of beef and chicken broth and a spicy puree of gembus (tofu dregs). It is made by boiling beef and chicken bones to get its broth and steaming gembus puree. Saute onion, garlic, candlenut, turmeric, coriander, and ginger puree and add chilli, salt, pepper and sugar. Add the sauted seasoning into gembus puree and put it into the broth. Add big green chilli and cabai rawit, let it cooked and become dense like porridge. It is served along with the chicken bones and kerupuk antor. The word glotak comes from the beef and chicken bones' sound hitting the pan when it is cooked with gembus puree.

Glotak is a traditional cuisine as snack made of beef and chicken bones broth, added with hot and spicy steamed gembus (tofu dregs) puree and served along with the chicken bones. This snack is usually found in school canteen or street food stall near offices or kampongs. Buyers commonly take it away and consume it with krupuk antor as topping

\section{Conclusion}

From the finding and discussion, the researcher found out that Tegal City people possess a pearl of local wisdom reflecting their way of thinking and life. They were utilizing abundant local natural resources such as goat and chicken from local sellers and onion, tempeh, tofu, gembus, soy sauce, or other vegetable-based products from farmers, producers, and sellers. This effort is made to keep the local livestock and crops and to empower local people's businesses. Unlike Savitri's research on Tegal Regency's new traditional cuisines [7] and Atrinawati's research on Tegal Regency's old traditional cuisines [8], this research shows how Tegal City people supported by the local government keep their traditional cuisine as part of the family tradition and the people prosperity since it is used in culinary tourism business to attract visitors who are interested in tasting famous traditional culinary items in the city. It shows that if the people who own a culture put an effort to keep their culture, it will not be shifted, replaced, endangered, extinct, or dead. Instead, it can be passed, learned, and even spread throughout the world.

\section{References}

[1] Taylor, E. Primitive Culture. Reasearches into Development of Mythology, Philosophy, Religion, Language, Art, and Custom. London: John Murray, Albermarle Street (1891)

[2] Holmes, J. An Introduction to Sociolinguistics. New York: Longman (1992)

[3] Wardaugh, R. An Introduction to Sociolinguistics. Massachusetts: Cambridge (1995)

[4] Sugiyono. Metode Penelitian Kualitatif dan R\&D. Bandung: CV Alfabeta (2010)

[5] Bronner, Editor. The Meaning of Folklore: The Analytical Essays of Alan Dundes. Logan, Utah: Utah State University Press, 2007

[6] Sudaryanto. Metode dan Aneka Teknik Analisis Bahasa. (Pengantar Penelitian Wacana Kebudayaan secara Linguistik). Yogyakarta: Duta Wacana (1993)

[7] Savitri, A.I. Introducing New Traditional Cuisine for Maintaining Culture and Promoting Tourism in Tegal Regency. Culturalistics: Journal of Cultural, Literary, and Linguistic Studies 3(2); 2019; 7-12. (2019)

[8] Atrinawati. Javanese Culture Maintenance by Keeping Traditional Javanese Food and Beverage Name in Tegal Regency Traditional Culinary Tourism. Culturalistics: Journal of Cultural, Literary, and Linguistic Studies 3(2); 2019; 41-46. (2019) 